\title{
Development of Nutrient Rich Extruded Product using Rice, Finger Millet, Soybean and Mango Seed Kernel Flour
}

\author{
P. S. Sapariya* , V. P. Sangani and M. H. Muliya
}

Department of Processing and Food Engineering, College of Agricultural Engineering and Technology, Junagadh Agricultural University, Junagadh, Gujarat, India-362001

*Corresponding author

\section{A B S T R A C T}

\section{Keywords}

Extruded product, Nutrient, Finger millet, Soybean and Mango Seed Kernel

\section{Article Info}

Accepted:

11 June 2020

Available Online:

10 July 2020

\begin{abstract}
Extrusion cooking is the technology, which transforms raw ingredients into ready-to-eat products, which is known as extruded product. Blends of different flours were used (i.e. rice, soybean, finger millet and mango seed kernel flour) in different proportion to increase the commercial value of extruded product. Study focuses to obtain desired proportion of rice, soybean, finger millet and mango seed kernel flour, determined the physical, functional, biochemical and sensory properties and increase the nutritional value of extruded product for acceptance of customer. The research were done at die temperature $\left(120^{\circ} \mathrm{C}\right)$, screw speed $(275 \mathrm{rpm})$ and feed moisture content $(18 \%$ w.b. $)$ as independent variables. Depending on sensory evaluation of the prepared extruded products, the feed composition was fixed as $75 \%$ rice, $5 \%$ finger millet, $7.5 \%$ soybean and $12.5 \%$ mango seed kernel flour. Extruded product prepared from decided feed composition increases true protein of $35.15 \%$ over control sample.
\end{abstract}

\section{Introduction}

Extrusion of foods is an emerging technology for the food industries to process large number of products of varying size, shape, texture and taste. Extrusion cooking is defined as a high temperature short time shear process used to transform raw ingredients into modified intermediate and finished products (Riaz, 2001).Extrusion technology has been used in the food industry for developing various products including precooked and modified starches, ready-to-eat (RTE) cereals, snack foods, texturized vegetable proteins (TVP), breading substitutes, etc (Harper and
Clark, 1979). Improvement in these basic products have continued since then to the present day to meet the needs of people. Extrusion technology involves continuous processing of food and includes one or more unit operations such as mixing, kneading and shaping a dough.

Cereals grains act as the major raw materials for the development of extruded product because they provide good expansion characteristics due to high starch content. Hence, extrusion processing of rice has been widely commercialized. In formulated readyto-eat products, they provide better mouth 
feel, texture and porosity of the products (Kadan et al., 2003).

Extruded products prepared from cereals are very low in protein and other functional components. For increasing the nutritional value of products, others ingredients are now being included in the product formulations. So, incorporating of soybean flour was reported to have a positive effect on protein of products because soybeans are rich source of proteins. Finger millet is used in extrusion cooking for enhance the calcium value of extruded product.

Nutritionally finger millet is considered as a rich source of calcium, iron, protein, fibre and other minerals. Specifically, it doesn't contain gluten, which makes it ideal to use in the formulation for the people who are suffering from either celiac disease, gluten sensitivity or gluten intolerance. Hence, these targeted groups can also consume the product made up from millet without risking their life (Salehifar and Shahedi, 2007).

Fruits and vegetables waste are also used for high dietary fibre content resulting with high water binding capacity and relatively low enzyme digestible organic matter (Serena and Knudsen, 2007).Abdalla et al., (2007) mentioned mango seed kernels have low content of protein but the quality of protein is good because it contains most of the essential amino acids with highest level of leucine, valine and lysine. Authors observed mango seed kernel is highly loaded with nutrients. Therefore, addition of mango seed kernel flour in food products is considered a good substitute for nutritional enhancement (Kittiphoom and Sutasinee 2013).

Extrusion cooking technology has led to production of wide variety of products like pasta, breakfast cereals and snack foods etc. Now a day, human are becoming more and more health conscious thus incorporating of novel ingredients in extrusion cooking becoming necessary and it can enhance the nutritional value of the products. Therefore, the focus of this research is to fix the feed composition (i.e. composite flour) of extruded product and increase the nutritional value of the extruded product. To achieve that, we have used the rice, finger millet, soybean and mango seed kernel flour as ingredients.

\section{Materials and Methods}

The important ingredients such as rice flour, soybean flour, finger millet flour and mango seed kernel flour were used for the development of extruded product.

\section{Preparation of different flour}

\section{Rice and soybean flour}

Rice and soybean were procured from the local market of Junagadh city. Rice and soybean grains were cleaned manually to remove all impurities and then grind it. After grinding, material was sieved to get uniform size of flour.

\section{Finger millet flour}

Finger millet was procured from the local market of Junagadh. Millet was soaked in water, after 12 hours take another vessel and place a clean cotton cloth over it then drain the water completely from the millet. Cotton cloth wrap it tightly and keep it in a dark place for sprouting for 24 hours.

Then millet was grind with adding water simultaneously and strain it. One more time grind it by adding water and again strain it. Then paste was prepared using wet grinder. The paste was dried to remove excess water. Then dried material was ground for getting finger millet flour. 


\section{Mango seed kernel flour}

The mango seeds were collected from the canning plant, washed with water and dried. The kernels were manually separated from the seeds and cleaned to remove of any adhering material. The kernels were chopped and dried at $50^{\circ} \mathrm{C}$. The dried material was ground in a hammer mill into flour and kept in airtight containers until further use (Abdalla et al., 2007).

\section{Preparation of composite flour}

The extruded product was developed from the composite flour containing rice flour, finger millet flour, soybean flour and mango seed kernel flour. The ratio of the different flours and level of independent of variable were decided based on the literature available on the extrusion cooking of different food raw materials.

Experiments were conducted to obtain desired proportion of mentioned different flour for preparing composite flour as per Table 1 . Extruded product was prepared with $120{ }^{\circ} \mathrm{C}$ die temperature, $275 \mathrm{rpm}$ screw speed and 18 $\%$ (w.b.) feed moisture content. After that, Based on sensory evaluation of prepared extruded products, which was got the maximum sensory score, was fixed the proportion of composite flour for preparing the extruded product and increasing the nutritional value.

\section{Preparation of extruded product}

The lab model co-rotating twin-screw extruder was used for extrusion. The barrel was provided with two electric and heaters and two water cooling jackets. The die temperature $120{ }^{\circ} \mathrm{C}$, screw speed $275 \mathrm{rpm}$ and feed moisture content $18 \%$ (w.b.) were set on the control panel. The die diameter was selected at $3 \mathrm{~mm}$ as recommended by the manufacturer for such type product. Composite flour was prepared for one treatment. From that, two samples were prepared. Then one sample was taken and added water to get high moisture content sample. It was fed in to feed hopper at the feeder speed of $14 \mathrm{rpm}$ for cleaning and starting operation. After that, another sample that contain desired moisture content was fed in to feed hopper at the $14 \mathrm{rpm}$ feeder speed $230 \mathrm{rpm}$ cutter speed. The extruded product was coming out in approx. $20 \mathrm{sec}$ after the feeding the flour. The extruded product was dried using laboratory tray drier at $60{ }^{\circ} \mathrm{C}$ temperature for 15 minute for the stabilization of moisture or to remove extra moisture from the product. The process flow chart for the preparation of extruded product is given in Fig. 1.

\section{Biochemical properties of composite flour}

Different essential properties of composite flour such as moisture content (\%), total carbohydrates (\%), fat (\%), total ash (\%), true protein $(\%)$, calcium $(\mathrm{mg})$ were determined as described in the subsequent section here under.

\section{Moisture content}

Moisture content was determined by hot oven drying method. In hot oven drying method the sample is heated under specific conditions and the loss of weight is used to calculate the moisture content of the sample (AOAC, 2005).

Moisture content (\% w.b.) $=\frac{W_{2}-W_{3}}{W_{2}-W_{1}} \times 100$

Where,

$\mathrm{W}_{1}=$ Mass of the dish

$\mathrm{W}_{2}=$ Mass of the dish and the sample before drying 
$\mathrm{W}_{3}=$ Mass of the dish and the sample after drying

\section{Total carbohydrate}

Total carbohydrate content of the prepared composite flour was determined by Phenol Sulphuric acid method (Dubois et al., 1956).Total carbohydrate content was calculated by using following formula.

Total carbohydrate $(\%)=\frac{\text { G.FXX 0.D.X Total volume X Dilution volume } \times 100}{\text { Sample aliquot X Weight of sample } \times 10^{6}}$

Where,

G.F. $=$ Graph factor

O.D. = Optical density

\section{Fat and ash}

Fat content of the composite flour in the sample was determined by Soxhlet extraction method and ash content of the composite flour was determined using muffle furnace as described by AOAC (2005).

Fat $(\%)=\frac{\text { weight of fat }}{\text { weight of sample }} \times 100$

Ash $(\%)=\frac{\text { weight of residue }}{\text { weight of sample }} \times 100$

\section{True protein and calcium}

True protein content of extruded product was determined by Folin-Lowry method (Lowry et al., 1951). Calcium content of extruded product was determined by Versenate EDTA method (Carr and Frank, 1956).

\section{Physical and functional properties of Extruded product}

\section{Bulk density}

The bulk density of dried extruded product was calculated by determining the volume of extruded product by filling a container of known volume and noting the sample weight (Mohsenin, 1986).

Bulk density $\left(\frac{\mathrm{kg}}{\mathrm{m}^{3}}\right)=\frac{\text { Mass of extrudate sample }}{\text { Volume of container }}$

\section{True density}

It was defined as mass per unit volume by same method as above but the volume determined was that of ground extruded product (Ali et al., 1996). The ground extruded product sample was filled into graduated cylinder and the volume occupied by sample was measured.

True density $\left(\frac{\mathrm{kg}}{\mathrm{m}^{3}}\right)=\frac{\text { Mass of ground extrudate ssample }}{\text { Volume occupied by ground extrudate sample }}$

\section{Expansion ratio}

The ratio of diameter of extruded product and the diameter of die was used to express the expansion of extruded product (Fan et al., 1996). The diameter of extruded product was determined as the mean of 10 random measurements made with a Venire calliper having least count $0.1 \mathrm{~mm}$.

Expansion ratio $(\mathrm{mm} / \mathrm{mm})=\frac{\text { Extrudate diameter }(\mathrm{mm})}{\text { Die diameter }(\mathrm{mm})}$

\section{Water Holding Capacity}

Approximately 5 grams of fine ground sample was weighed and allowed to rehydrate overnight in excess water (7:1). After draining, it was reweighed and WHC calculated as following (Neumann et al., 1984).

Water Holding Capacity $(\%)$

$$
=\frac{\text { Mass of wet extrudate powder }- \text { Mass of dry estrudate powder }}{\text { Mass of dry extrudate powder }} \times 100
$$


Biochemical properties of extruded product

\section{True protein and calcium}

True protein content of extruded product was determined by Folin-Lowry method (Lowry et al., 1951). Calcium content of extruded product was determined by Versenate EDTA method (Carr and Frank, 1956).

\section{Sensory evaluation of extruded product}

The sensory analysis of prepared extruded product was carried out by 9-Point hedonic scale method given by (Ranganna, 1986).

All the extruded product was judged by twelve panellists for its quality parameters like taste, chewiness, colour, appearance and overall acceptability on the given score sheet based on the degree of preference.
The panellists were given a short training session on how to use the score sheet and the meaning of sensory characteristics in score sheet were explained.

\section{Results and Discussion}

Extruded product prepared from rice flour (control)

The analysis of the extruded product prepared from the rice flour was carried out and the data regarding various properties of extruded product present in the Table 2. The experiments were replicated three times and average values are reported.

\section{Extruded products from composite flour}

Extruded products were prepared from the different composite flour as per Table 1. The photographs of prepared extruded products are given in Fig. 2

Table.1 Proportion of different flour for experiment

\begin{tabular}{|c|c|c|c|c|c|c|}
\hline \multirow[t]{2}{*}{ Trials No. } & \multirow{2}{*}{$\begin{array}{c}\text { Feed } \\
\text { composition }\end{array}$} & \multirow{2}{*}{$\begin{array}{c}\text { Rice } \\
\text { flour } \\
(\%)\end{array}$} & \multicolumn{3}{|c|}{ Ingredient flour (\%) } & \multirow[t]{2}{*}{ Total } \\
\hline & & & $\begin{array}{c}\text { Finger } \\
\text { millet } \\
(\%)\end{array}$ & $\begin{array}{c}\text { Soybean } \\
(\%)\end{array}$ & $\begin{array}{c}\text { Mango } \\
\text { seed } \\
\text { kernel } \\
(\%)\end{array}$ & \\
\hline 1 & \multirow[t]{5}{*}{1} & \multirow[t]{5}{*}{75} & 5 & 5 & 15 & 100 \\
\hline 2 & & & 5 & 7.5 & 12.5 & 100 \\
\hline 3 & & & 5 & 10 & 10 & 100 \\
\hline 4 & & & 5 & 12.5 & 7.5 & 100 \\
\hline 5 & & & 5 & 15 & 5 & 100 \\
\hline 6 & \multirow[t]{5}{*}{2} & \multirow[t]{5}{*}{50} & 10 & 10 & 30 & 100 \\
\hline 7 & & & 10 & 15 & 25 & 100 \\
\hline 8 & & & 10 & 20 & 20 & 100 \\
\hline 9 & & & 10 & 25 & 15 & 100 \\
\hline 10 & & & 10 & 30 & 10 & 100 \\
\hline 11 (control) & 3 & 100 & 0 & 0 & 0 & 100 \\
\hline
\end{tabular}


Table.2 Different physicochemical properties of extruded product prepared from rice flour

\begin{tabular}{|c|l|c|c|c|c|}
\hline \multirow{2}{*}{ Sr. No. } & Parameters & \multicolumn{3}{|c|}{ Sample } & Average \\
\cline { 3 - 5 } & & $\mathbf{1}$ & $\mathbf{2}$ & $\mathbf{3}$ & \\
\hline 1. & Moisture content $(\%$ w.b.) & 9.61 & 8.91 & 9.23 & 9.25 \\
\hline 2. & Bulk density $\left(\mathrm{kg} / \mathrm{m}^{3}\right)$ & 135.46 & 131.3 & 133.56 & 133.44 \\
\hline 3. & True density $\left(\mathrm{kg} / \mathrm{m}^{3}\right)$ & 630.02 & 648.88 & 652.53 & 643.81 \\
\hline 4. & Expansion ratio $(\mathrm{mm} / \mathrm{mm})$ & 3.36 & 3.67 & 3.17 & 3.4 \\
\hline 5. & Water holding capacity $(\%)$ & 541.36 & 537.49 & 542.26 & 540.37 \\
\hline 6. & True protein $(\%)$ & 1.96 & 2.15 & 1.94 & 2.02 \\
\hline 7. & Total carbohydrate $(\%)$ & 69.56 & 71.53 & 75.99 & 72.33 \\
\hline 8. & Calcium $(\mathrm{mg} / 100 \mathrm{~g})$ & 46 & 48 & 38 & 44 \\
\hline
\end{tabular}

Table.3 Sensory evaluation score of extruded products from different composite flour

\begin{tabular}{|c|c|c|c|c|c|}
\hline \multirow{2}{*}{ Samples } & \multicolumn{5}{|c|}{ Sensory characteristics } \\
\cline { 2 - 5 } & Taste & Chewiness & Colour & Appearance & $\begin{array}{c}\text { Overall } \\
\text { acceptability }\end{array}$ \\
\hline $\mathbf{1}$ & 5.25 & 5.67 & 6.00 & 6.00 & 5.67 \\
\hline $\mathbf{2}$ & 6.58 & 6.92 & 7.25 & 6.83 & 7.17 \\
\hline $\mathbf{3}$ & 5.17 & 5.75 & 6.00 & 5.83 & 5.54 \\
\hline $\mathbf{4}$ & 5.17 & 5.33 & 6.00 & 5.92 & 5.50 \\
\hline $\mathbf{5}$ & 5.50 & 5.58 & 5.92 & 5.67 & 5.71 \\
\hline $\mathbf{6}$ & 4.50 & 4.50 & 4.17 & 4.33 & 4.63 \\
\hline $\mathbf{7}$ & 3.67 & 3.33 & 3.83 & 3.92 & 3.67 \\
\hline $\mathbf{8}$ & 4.75 & 4.92 & 5.00 & 4.92 & 4.83 \\
\hline $\mathbf{9}$ & 5.42 & 5.83 & 5.50 & 5.33 & 5.58 \\
\hline $\mathbf{1 0}$ & 5.92 & 5.67 & 5.42 & 5.33 & 5.50 \\
\hline
\end{tabular}

Table.4 Biochemical properties of the decidedcomposite flour

\begin{tabular}{|c|l|c|}
\hline Sr. No. & Parameters & Average value \\
\hline $\mathbf{1}$ & Moisture content $(\% \mathrm{w.b})$ & $9.85 \pm 0.09$ \\
\hline $\mathbf{2}$ & Total carbohydrates $(\%)$ & $76.43 \pm 0.89$ \\
\hline $\mathbf{3}$ & True protein $(\%)$ & $4.22 \pm 0.24$ \\
\hline $\mathbf{4}$ & Fat $(\%)$ & $4.76 \pm 0.52$ \\
\hline $\mathbf{5}$ & Total ash $(\%)$ & $1.04 \pm 0.02$ \\
\hline $\mathbf{6}$ & Calcium $(\mathrm{mg} / 100 \mathrm{~g})$ & $60 \pm 0.94$ \\
\hline
\end{tabular}


Table.5 Different properties of extruded product prepared from decided composite flour

\begin{tabular}{|c|l|c|}
\hline Sr. no. & Parameters & Average value \\
\hline $\mathbf{1}$ & Moisture content $(\%$ w.b. $)$ & 8.44 \\
\hline $\mathbf{2}$ & Bulk density $\left(\mathrm{kg} / \mathrm{m}^{3}\right)$ & 241.04 \\
\hline $\mathbf{3}$ & True density $\left(\mathrm{kg} / \mathrm{m}^{3}\right)$ & 771.95 \\
\hline $\mathbf{4}$ & Expansion ratio $(\mathrm{mm} / \mathrm{mm})$ & 2.53 \\
\hline $\mathbf{5}$ & Water holding capacity $(\%)$ & 355.54 \\
\hline $\mathbf{6}$ & True protein $(\%)$ & 2.73 \\
\hline $\mathbf{7}$ & Calcium $(\mathrm{mg} / 100 \mathrm{~g})$ & 44 \\
\hline $\mathbf{8}$ & Total carbohydrate $(\%)$ & 65.92 \\
\hline $\mathbf{9}$ & Sensory score & 7.17 \\
\hline
\end{tabular}

Fig.1 Process flow chart for the preparation of extruded product

Composite flour

(Rice flour, Finger millet, Soybean,

Mango seed kernel flour)

Addition of water

(18\% (w.b.))
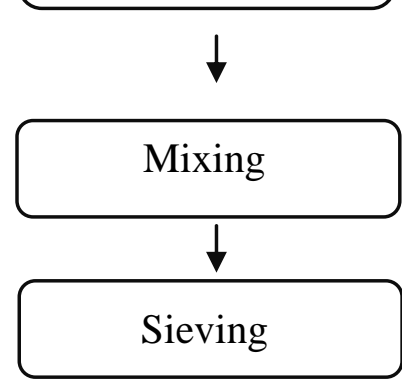

$\downarrow$

Extrusion (Twin-screw extruder)

(Die temperature: $120^{\circ} \mathrm{C}$,

Screw speed: $275 \mathrm{rpm}$ )

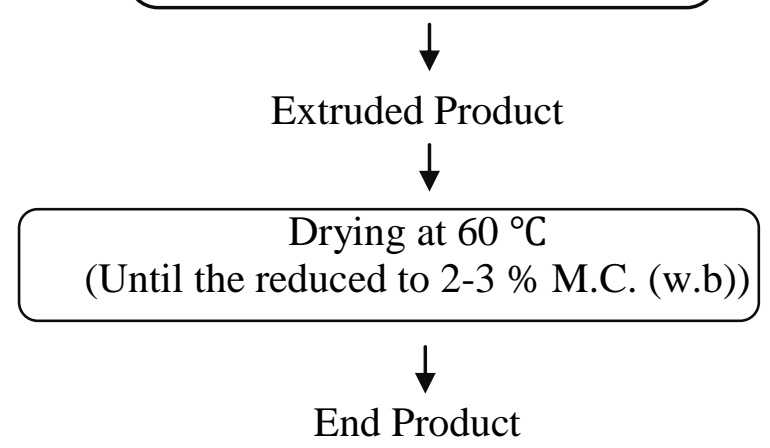


Fig.2 Extruded products from different composition flour

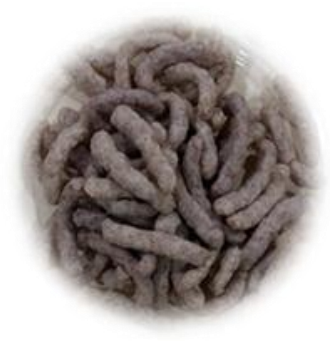

$\mathrm{T} 1$

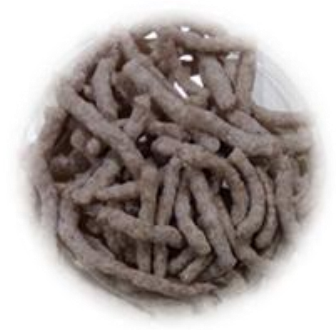

$\mathrm{T} 4$

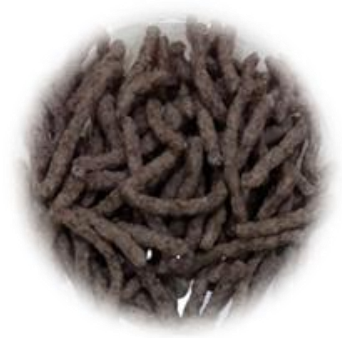

$\mathrm{T} 7$

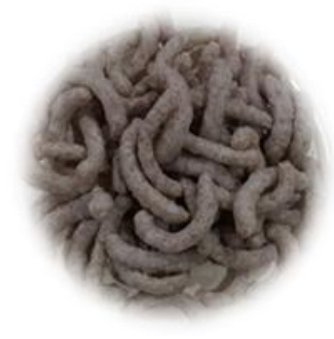

$\mathrm{T} 2$

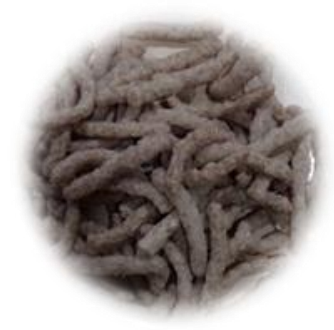

T5

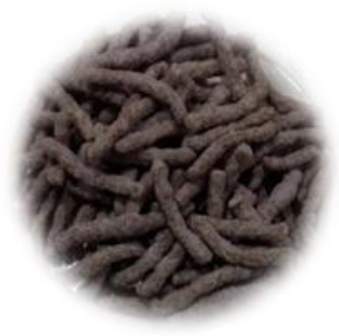

$\mathrm{T} 8$

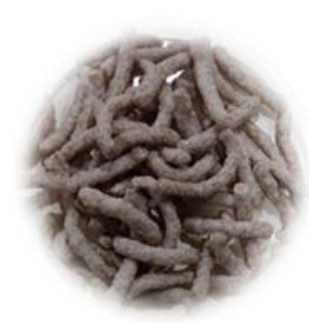

$\mathrm{T} 3$

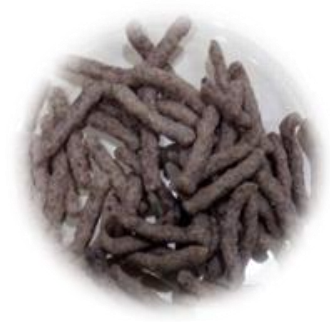

T6

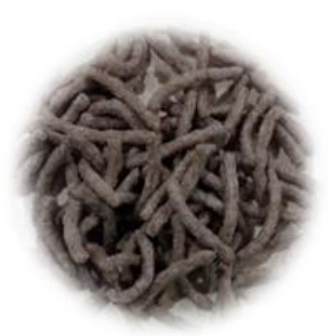

T9

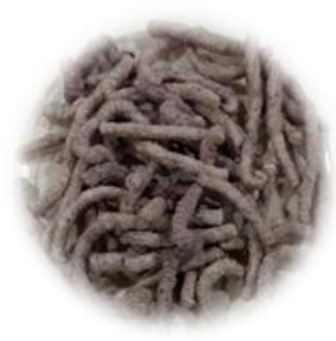

$\mathrm{T} 10$

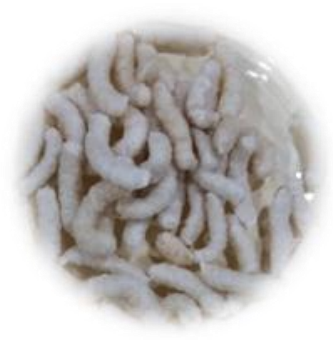

T11 (control)

\section{Optimize the composite flour}

Optimum composition for the development of nutrient rich extruded product using rice, finger millet, soybean and mango seed kernel flour was determined by the sensory evaluation of the prepared extruded products. Sensory evaluation score given in Table 3. According to the sensory score, sample- 2 has better taste, chewiness, colour, appearance and overall acceptability than others.

Therefore, feed composition of sample- 2 was fixed for development of nutrient rich extruded product. Feed composition as $75 \%$ rice, $5 \%$ finger millet, $7.5 \%$ soybean and $12.5 \%$ mango seed kernel flour was fixed. 


\section{Biochemical properties of decided composite flour}

Biochemical properties of decided composite flour viz., moisture content, total carbohydrates, true protein, fat content, ash content and calcium are tabulated in Table 4.

\section{Properties of extruded product}

Physicochemical and functional properties of extruded product prepared from decided composite flour, viz., moisture content, bulk density, true density, expansion ratio, water holding capacity, true protein, calcium, total carbohydrate and sensory score are tabulated in Table 5.

In conclusion composite flour was prepared from proportion of $75 \%$ rice flour, $5 \%$ finger millet flour, $7.5 \%$ soybean flour and $12.5 \%$ mango seed kernel flour. It can be suggested for enhance the nutritional value of extruded product with $120^{\circ} \mathrm{C}$ die temperature, $275 \mathrm{rpm}$ screw speed and 18\% (w.b.) feed moisture content which gave the values of true protein $2.73 \%$ and calcium $44 \mathrm{mg} / 100 \mathrm{~g}$. In control sample, true protein and calcium were found to be $2.02 \%, 44 \mathrm{mg} / 100 \mathrm{~g}$, respectively. Hence, there was an increase in true protein of $35.15 \%$ over control sample and calcium was equal to control sample.

\section{Future aspects}

In future study, we can also study the effect of different range of given independent parameters (i.e. die temperature, screw speed and feed moisture content) on different characteristics of extruded product. In this research, we can use the concluded composite flour (i.e. $75 \%$ rice flour, $5 \%$ finger millet flour, $7.5 \%$ soybean flour and $12.5 \%$ mango seed kernel flour) as a feed composition for preparing extruded product.

\section{References}

Abdalla, A. E. M., Darwish, S. M., Ayad, E. H. E. and El-Hamahmy, R. M. 2007. Egyptian Mango by-product compositional quality of mango seed kernel. Food Chemistry. 103: 11341140.

Ali, Y., Hanna, M. A. and Chinnaswamy, R. 1996. Expansion characteristics of extruded corn grits. LWT-Food Science and Technology. 29(8): 702-707.

AOAC 2005. Official Methods of Analysis of the AOAC International, 18th edition, Gaithersburg, MD, USA.

Carr, M. H., and Frank, H. A. 1956. Improved method for determination of calcium and magnesium in biologic fluids by EDTA titration. American Journal of Clinical Pathology. 26: 1157-1168.

Dubois, M, Gilles, K A, Hamilton, J K, Rebers, P A and Smith, F (1956) Anal Chem 26: 350

Fan, J., Mitchell J. R. and Blanchard, J. M. V. 1996. The effect of sugars on the extrusion of maize grits: the role of the glass transition in determining product density and shape. International Journal of Food Science and Technology. 31: 55-65.

Harper, J. M., and Clark, J. P. 1979. Food extrusion. Critical Reviews in Food Science and Nutrition. 11(2): 155-215.

Kadan, R. S., Bryant, R. J., and Pepperman, A. B. 2003. Functional properties of extruded rice flours. Journal of Food Science. 68(5): 1669-1672.

Kittiphoom, S. and Sutasinee, S. 2013. Mango seed kernel oil and its physicochemical properties. International Food Research Journal. 20(3):1145-1149.

Lowry, O. H., Rosebrough, N. J., Farr, A. L. and Randall, R. J. 1951. Protein measurement with the Folin phenol reagent. Journal of Biochemistry. 193: 265-275 
Mohsenin, N. N. 1986. Physical properties of plant and animal materials. Golden and Breach Sci. Publishers, New York.

Neumann, P. E., Jasberg, B. K., Wall, J. S. and Walker, C. E. 1984. Uniquely textured products obtained by coextrusion of corn gluten meal and soy flour. Cereal Chemistry. 61(5): 439.

Ranganna, S. 1986. Handbook of Analysis and Quality Control for Fruit and Vegetable Products. McGraw-Hill Education (India) Private Limssssited, Chennai.

Riaz, M. N. 2001. Extrusion cooking. In R. Guy (Ed.), selecting the right extruder (pp. 200). Cambridge CB1 6AH, England: Woodhead Publishing Limited and CRC Press LLC.

Salehifar, M. and Shahedi, M. 2007. Effects of oat flour on dough rheology, texture and organoleptic properties of taftoon bread. Journal of Agricultural Science and Technology. 9: 227-234.

Serena, A. and Knudsen, K. B. 2007. Chemical and physicochemical characterisation of co-products from the vegetable food and agro industries. Animal Feed Science and Technology. 139(1-2): 109-124.

\section{How to cite this article:}

Sapariya, P. S., V. P. Sangani and Muliya, M. H. 2020. Development of Nutrient Rich Extruded Product Using Rice, Finger Millet, Soybean and Mango Seed Kernel Flour. Int.J.Curr.Microbiol.App.Sci. 9(07): 1207-1216. doi: https://doi.org/10.20546/ijcmas.2020.907.139 